http://dx.doi.org/10.1590/1678-4162-9464

Arq. Bras. Med. Vet. Zootec., v.69, n.6, p.1560-1564, 2017

\title{
Use of moxibustion as an auxiliary treatment in wound healing of the snake Eunectes murinus (anaconda): case report
}

\author{
[Uso da moxabustão como tratamento auxiliar em ferimentos na serpente \\ Eunectes murinus (anaconda): relato de caso]$$
\text { V.C. Garcia }{ }^{1,2} \text {, C.V. Prado }{ }^{2}
$$ \\ ${ }^{1}$ Instituto Butantan - São Paulo, SP \\ ${ }^{2}$ Faculdade de Medicina Veterinária e Zootecnia - USP - São Paulo, SP
}

\begin{abstract}
Large snakes of the Boidae family, such as Eunectes murinus, require special techniques to facilitate their care when they are sick. Thus, an acupuncture technique called moxibustion was applied that utilizes burning of the weed Artemisia vulgaris for heating at specific points on the skin without handling the animals. The objective of this case report was to describe the use of moxibustion acupuncture as an auxiliary treatment for snakes. A female, 4.0 meters long and weighing about $30 \mathrm{~kg}$, belonging to a Biological Museum of the Butantan Institute, showed symptoms of weight loss, anorexia and hyperemia in the ventral region. The snake was examined and treated with ciprofloxacin antibiotics and a month showed an area of necrosis that exposed the muscles in the dorsal cranial region. The female was treated with moxibustion and application of silver sulfadiazine cream at the site of the lesion. After seven months of treatment, the animal showed signs of good healing with complete wound closure. This technique of moxibustion could be easily applied without restraint, an important detail given the size of the snake, and with successful closure of the lesion.
\end{abstract}

Keywords: snake, acupuncture, moxibustion, Artemisia vulgaris, Eunectes murinus

\section{RESUMO}

Grandes serpentes da família Boidae, como Eunectes murinus, requerem técnicas especiais para facilitar seus cuidados quando estão doentes. Assim, uma técnica de acupuntura, chamada de moxabustão, foi aplicada utilizando-se a queima da erva Artemisia vulgaris para aquecer pontos específicos na pele, sem manusear os animais. O objetivo deste relato de caso foi descrever o uso da acupuntura moxabustão como um tratamento auxiliar para serpentes. Uma fêmea com 4,0m de comprimento e pesando cerca de $30 \mathrm{~kg}$, pertencente ao Museu Biológico do Instituto Butantan, apresentou sintomas de perda de peso, anorexia e hiperemia na região ventral. A serpente foi examinada e tratada com o antibiótico ciprofloxacina e um mês depois mostrou uma área de necrose, que expôs os músculos da região dorsal cranial. A fêmea foi tratada com moxabustão e aplicação do creme de sulfadiazina de prata no local da lesão. Depois de sete meses de tratamento, o animal mostrou sinais de boa cicatrização, com fechamento completo da ferida. Essa técnica de moxabustão pode ser facilmente aplicada sem restrição, um detalhe importante dado o tamanho da serpente, e com fechamento bem-sucedido da lesão.

Palavras-chave: serpente, acupuntura, moxabustão, Artemisia vulgaris, Eunectes murinus

\section{INTRODUCTION}

Wound management in reptiles follows the same basic methods as in higher vertebrates (Mitchell and Diaz-Figueroa, 2004). However, a temporal

Recebido em 23 de setembro de 2016

Aceito em 11 de janeiro de 2017

E-mail: vivianecgarcia@hotmail.com sequence of healing is observed in garter snakes (Thammnophis sirtalis) and exhibit differences in inflammatory reaction, pattern of fibroplasia and dermal and epidermal repair, compared to mammals. The healing process in these ectodermal animals is largely dependent on the 
environmental temperature (Smith and Barker, 1988). In the common garter snake (Thamnophis sirtalis), better results in wound healing were achieved at higher temperatures based on rates of re-epithelialization, dermal fibroplasia, initiation and resolution of inflammation (Smith et al., 1988). Animals maintained at $30^{\circ} \mathrm{C}$ presented earlier epithelial cell migration compared to $21^{\circ} \mathrm{C}$ and $13.5^{\circ} \mathrm{C}$, respectively (Smith and Barker, 1988).

Many wounds, especially those that may be infected, are best managed by second intention wound healing (healing process without closuring of the wound tissue) (Swaim and Henderson, 1990). The physiologic course of this healing is by wound contraction from natural epithelial migration, which can require days to weeks. Linear wounds heal at a faster rate than circular or square wounds in snakes (Smith and Barker, 1988). The techniques for wound treatment in reptiles are based on cleaning the injured tissue using warm saline solution, debridement of devitalized areas and protection against desiccation and secondary infections (Mitchell and Diaz-Figueroa, 2004). Other complementary procedures can be used to enhance the speed of lesion healing, including use of antibacterial compounds, antiseptics and occlusive dressings (Clarck, 1980; Amber et al., 1983).

Moxibustion involves stimulating specific areas on the skin (acupuncture points or damaged area) by burning the herb Artemisia vulgaris directly or indirectly closer to or on the skin, respectively (Schoen, 2006; Xie and Preast, 2011). Studies in wound healing in rats found an incremental benefit using indirect moxibustion in refractory skin ulcers (Sun et al., 2001; Sun et al., 2012) full-thickness, linear skin injuries and anal fistula wounds. Since the recovering tissue growth after injury in reptiles is variable and often needs longer recuperation than other vertebrates (Rinaldi et al., 2013), moxibustion presents a good complementary approach for enhancing wound healing in snakes.

The objective of this study was to report the feasibility of moxibustion as a complementary treatment for necrotic injury following ciprofloxacin injections in an anaconda snake (Eunectes murinus).

\section{CASUISTRY}

The snake measured 4.5 meters, with an approximate mass of $30 \mathrm{~kg}$, and was housed at the Biological Museum, Butantan Institute, São Paulo, Brazil. It presented hyperemia at the ventral face of the body, which could suggest dermatitis or septicemia. Suspecting an infectious process, environment bacterial culture was performed, resulting in high growth of Pseudomonas spp. The snake was treated with injectable ciprofloxacin $(10 \mathrm{mg} / \mathrm{kg} / 72 \mathrm{~h})$ for 15 days. However, after the treatment (5 intramuscular applications), the animal underwent ecdysis and a necrotic area with muscle exposure at the injection site was observed (dorsal cranial region). Following, a sulfa antibiotic was applied in the lesion local once a week. After this process, the moxibustion treatment began. Indirect moxibustion was performed with a traditional Artemisia moxa stick attached to a snake hook and carried out weekly in 10-minute sessions for 7 months.

After seven months of treatment, the animal showed good healing with complete wound closure (Figure 1). During this period, the snake presented four ecdysis at intervals of two to three months. 

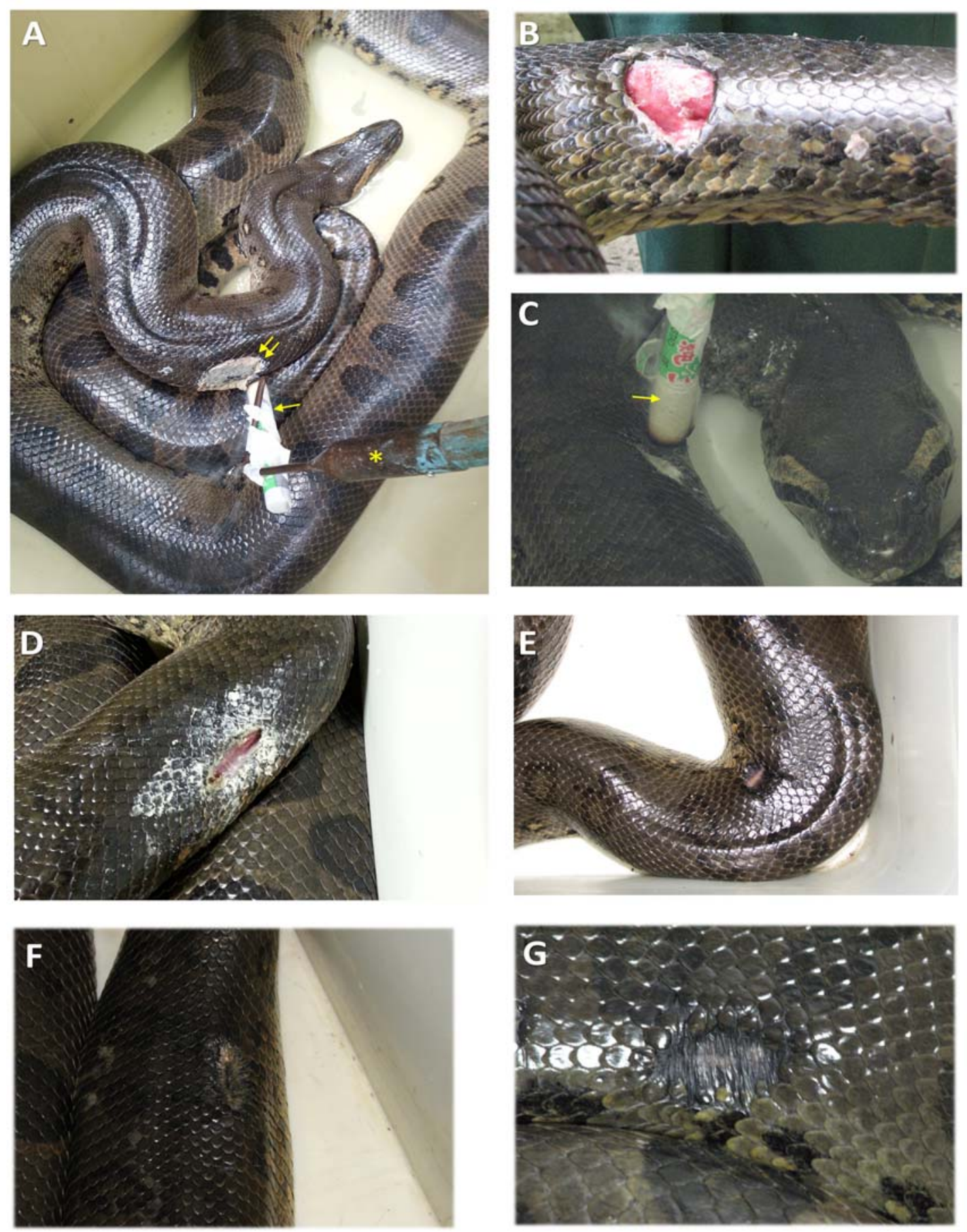

Figure 1. Progression of wound healing on the right side of the anaconda snake. A) Necrotic tissue adhering to the wound (double yellow arrow) in early stages of healing. Moxibustion stick (single yellow arrow) attached to a snake hook (*) with white tape; B) Laceration on the right side following removal of necrotic tissue C) Treatment after one month. Moxibustion stick (yellow arrow); D) Treatment after two months; E) Treatment after three months; F) Treatment after six months; G) Complete cicatrization after seven months. 


\section{DISCUSSION}

Use of quinolone family antibiotics, which includes ciprofloxacin, in subcutaneous or intramuscular injection can cause local reaction leading to panniculitis or necrosis (Clark, 1980). Thus, caution is indicated in administration of this drug (Andrade and Giuffrida, 2008). The intramuscular injection of ciprofloxacin in the snake of the case report may have been one of the probable causes that led to the necrotic process.

Ecdysis is a normal physiological occurrence in reptiles and is related to animal growth and tissue renewal (Smith and Barker, 1988). In experimental wound evaluation in snakes, a more intense epithelial proliferation in snakes during ecdysis was present, which could have accelerated cell division to assist in covering the wound (Smith et al., 1988). Nonetheless, the long interval between moulting in adult snakes leads to a longer healing process. Therefore, the study of techniques that could accelerate wound healing in these animals is important because, in addition to reducing the risk of complications such as secondary infections, it leads to less manipulation of the animal.

In experimental studies, moxibustion was shown to facilitate the healing process (Sun et.al., 2001; Sun et.al., 2012). In a model of chronic refractory skin ulceration in rats, moxibustion was associated with increasing the healing rate and reducing the healing time, increasing blood flow volume, microvessel count and the concentration of vascular endothelial growth factor (VEGF) at the raw surface of the wound (Sun et.al., 2001). Additionally, moxibustion was associated with up-regulation of the concentration of macrophages at beginning of injury (until day 10) and with down-regulation in the later inflammatory process $\left(14^{\text {th }}\right.$ day), and with up-regulation of collagen I and III expression at the raw surface tissue, which may contribute to wound healing and reducing scar formation (Sun et.al., 2012). Further, a study in linear full-thickness skin injury in rats showed that moxibustion treated animals had higher healing indices, associated with vascular endothelial cell and vascular endothelial growth factor regulation at different times (increased at day 3 and decreased at day 7) (Sun et al., 2012).
Secondary infections are also an obstacle for wound healing that appear to be minimalized by moxibustion. Moxibustion smoke has antibacterial and disinfectant functions. The smoke can be used to disinfect hematology and hematopoietic stem cell transplantation wards, with notable effects in reduction of colony counts of Staphylococcus aureus and Pseudomonas aeruginosa. Infected wounds have also been investigated. Anal fistulae were used as an acute, open, bleeding and infected wound surface in rats. In the early and middle stages of wound healing, moxibustion obviously increased the expression of VEGF, the number of positive CD34 cells (a hematopoietic stem cell marker), and the blood flow at the wound surface. After a peak on day 7, VEGF expression, CD34+ cells and blood flow on wound surface began to decrease, until day 14 (last day evaluated) (Sun et al., 2001). These regulative actions could regulate microcirculation and promote wound healing. In the present case report, it cannot be claimed that moxibustion increased the wound healing process due to the lack of control group treatment. However, the absence of secondary infections and total cicatrization of wound together with previous research on moxibustion might indicate a positive influence, although only with an experimental and control group study this statement can be confirmed.

Large snakes of the Boidae family, such as Eunectes murinus (anaconda), require special techniques to facilitate their management when sick including reducing handling of the animal to a minimum. Concerning this case report, the delayed time for complete wound cicatrization in the anaconda can be attributed to the wound extension on muscle and dermal tissue. Because the total closure of the injury was achieved without any interruption of the healing process or need for physical restraint, this facilitates handling of large and/or venomous snakes. Additionally, the moxibustion stick attached to the snake hook allowed applying the therapy with a secure distance from the animal, without restraining it.

Regardless, all safety precautions must be followed, especially when treating venous and/or big snakes. Always when possible, place or maintain the animal in a container compatible to its size to perform moxibustion, keeping a safe distance from the animal (using the moxibustion 
stick attached in a stick or snake hook) with another restraining tool accessible. It is preferred that two people handle the animal, one to perform moxibustion and another to avoid the animal's escape or attack. If physical restraint is necessary, a trained person must restrain the animal while another applies moxibustion. Depending on the size of the animal, more than one person is needed to restrain the snake.

\section{CONCLUSIONS}

Moxibustion can easily be performed in anaconda snakes (Eunectes murinus) as a complementary treatment to enhance wound healing. Also, there were no side effects or secondary infections observed from beginning of treatment until total injury cicatrization. Based on this study and previous observations of others, moxibustion appears to improve the rate of wound healing in snakes. However, further studies are required to confirm this conclusion.

\section{ACKNOWLEDGEMENTS}

The authors thank director Giuseppe Puorto and collaborators of the Biological Museum for assistance and the teacher Peter Pearson for the discussion and editorial assistance.

\section{REFERENCES}

AMBER, E.I.; HENDERSON, R.A.; SWAIM, S.F.; GRAY, B.W. A comparison of antimicrobial efficacy and tissue reaction for four antiseptics on canine wounds. Vet. Surg., v.12, p.63-68, 1983.

ANDRADE, S.F.; GIUFFRIDA, R. Quimioterápicos antimicrobianos e antibióticos. In: ANDRADE, S.F. (Ed.). Manual de terapêutica veterinária. São Paulo: Roca, 2008. p.41-42.
CLARK, C.H. Use of antibiotics in wounds. Mod. Vet. Pract., v.61, p.307-312, 1980.

MITCHELL, M.A.; DIAZ-FIGUEROA, O. Wound management in reptiles. Vet. Clin. N. Am. Exot. Anim. Pract., v.7, p.123-140, 2004.

RINALDI, S.; IANNACCONE, M.; MAGI, G.E. et al. Physical reparative treatment in reptiles. BMC Vet. Res. v.9, p.39, 2013.

SCHOEN, A.M. (Ed.) Acupuntura veterinária: da arte antiga à medicina moderna. São Paulo: Roca, 2006. 624p.

SMITH, D.A.; BARKER, I.K. Healing of cutaneous wounds in the common garter snake (Thamnophis sirtalis). Can. J. Vet. Res., v.52, p.111-119, 1988.

SMITH, D.A.; BARKER, I.K.; ALLEN, B.O. The effect of ambient temperature and type of wound on healing cutaneous wounds in the common garter snake (Thamnophis sirtalis). Can. J. Vet. Res., v.52, p.120-128, 1988.

SUN, L.H.; LIANG, Y.L.; SUN, Y.H. et al. Effect of mild moxibustion on macrophage number and collagen expression of raw surface tissue in chronic refractory skin ulcer rats. Zhen Ci Yan Jiu (Acupunct. Res.), v.37, p.259-265, 2012.

SUN, Y.H.; SUN, L.H.; LIANG, Y.L. et al. Effect of mild-warm moxibustion on microcirculation in the raw surface tissue of chronic refractory wound in skin ulcer rats. Zhen Ci Yan Jiu (Acupunct. Res.), v.36, p.321-326, 2001.

SWAIM, S.F.; HENDERSON, R. Secondary management. In: SWAIN, S.F.; HENDERSON, R. Small animal wound management. Philadelphia: Lea and Febiger, 1990. p.17-28.

XIE, H.; PREAST, V. (Eds.). Acupuntura veterinária xie. São Paulo: MedVet, 2011. 363p. 